\title{
TEMPORAL SHORELINE SERIES ANALYSIS USING GNSS
}

\author{
Análise temporal da linha de costa utilizando GNSS \\ FRANCISCO JAIME BEZERRA MENDONÇA ${ }^{1}$ \\ RODRIGO MIKOSZ GONÇALVES ${ }^{1,2}$ \\ JOSEPH AWANGE ${ }^{2}$ \\ LUCIANA MARIA DA SILVA ${ }^{1}$ \\ MARIA DAS NEVES GREGÓRIO ${ }^{3}$
}

${ }^{1}$ Department of Cartographic Engineering, Geodetic Science and Technology of Geoinformation Post Graduation Program, Federal University of Pernambuco (UFPE), Recife, PE, Brazil.

${ }^{2}$ Department of Spatial Sciences, Curtin University, Perth, WA, Australia. ${ }^{3}$ Instituto de Tecnologia de Pernambuco (ITEP), Recife, PE, Brazil. jaime@ufpe.br; rodrigo.mikosz@ufpe.br; J.Awange@curtin.edu.au;

luciana_maria15@hotmail.com; nevesgregorio@hotmail.com.

\begin{abstract}
In recent decades, Boa Viagem beach located in the city of Recife-PE and Piedade in Jaboatão dos Guararapes-PE (Brazil) has seen urbanization near the coastline causing changes in social, economic and morphological aspects, where coastal erosion problems are observed. This study uses GNSS (global navigation satellite system) shoreline monitoring approach, which is quicker, and provides continuously updatable data at $\mathrm{cm}$-level accuracy to analyze and determine temporal positional shifts of the shoreline as well as annual average rates through EPR (end point rate). To achieve this, kinematic GNSS survey data for the years 2007, 2009, 2010 and 2012 were used. The results show sectorial trends over the years, with the highest annual retreat rate of $8.16 \mathrm{~m}$ /year occurring during the period 2007-2009. Variety of differents patterns over the shoreline was also observed. These findings could be essential for decision making in coastal environments.
\end{abstract}

Keywords: Shoreline; Monitoring; GNSS; Coastal Erosion; Coastal Settlement.

\section{RESUMO}

Nas últimas décadas, a praia de Boa Viagem localizada no município de Recife-PE e de Piedade no município de Jaboatão dos Guararapes-PE vem sendo urbanizadas 
próximas à linha de costa provocando grandes transformações nas relações sociais, econômicas e morfológicas, onde problemas de erosão costeira são observados. O presente trabalho faz uso monitoramento da linha de costa utilizando o GNSS (global navigation satellite system) que oferece rapidez, repetibilidade e acurácia centimétrica para determinar e analisar os deslocamentos temporais da linha de costa assim como as taxas de deslocamento médias através do EPR (end point rate). Para isso, foram utilizados dados obtidos através de levantamentos geodésicos relativos cinemáticos para os anos de 2007, 2009, 2010 e 2012. Os resultados representam tendências setoriais através dos anos onde a maior taxa de recuo encontrada foi de $8,16 \mathrm{~m} / \mathrm{ano}$, encontrada no período de 2007-2009. Uma variedade de diferentes padrões sobre a linha de costa foram observados. Os resultados obtidos são considerados fundamentais para tomada de decisão em ambientes costeiros.

Palavras-chave: Linha de Costa; Monitoramento; GNSS; Erosão Costeira; Ocupação Costeira.

\section{INTRODUCTION}

A shoreline is one of the most dynamic geomorphological features of our planet. Several studies involving its concept and modeling have been developed both nationally in Brazil (TANAJURA et al., 2011; GONÇALVES et al., 2010; ALMEIDA, 2008; ROCHA et al., 2008; RIBEIRO, 2005; ANGULO, 1996), and globally (SMITH and CROMLEY, 2012; JACKSON et al., 2012; BAPTISTA et al., 2011; STOCKDON et al., 2002; THIELER and DANFORTH, 1994, among others). The shoreline monitoring is necessary for the purpose of integrating coastal zone management (ICZM), where the positional and dynamical information are fundamental for territorial planning, as well as for learning the process of coastal evolution providing information to protect, plan, and make decisions in relation to coastal environment (VELOSO-GOMES et al., 2008; TZATZANIS et al., 2003).

Shoreline monitoring at higher temporal resolution is essential for mitigating the impacts of coastal erosion that has recently featured prominently in the Brazilian news. Coastal erosion in Brazilian beaches, e.g., Boa Viagem beach in the city of Recife-PE and Piedade in Jaboatão dos Guararapes-PE are known to cause socioeconomic problems, whereby they usually result from a combination of natural and human factors. In temporal terms, it is common to find coastal changes classified as long-term and short-term. Long-term may be related to changes in average sea level, sediment transport, wave energy, geological controls (contemporaries and antecedents) causing changes in its position over a period of hundred or thousands of years. Short-term, however, may occur on time scales of decades or smaller and are related to daily movement, monthly or seasonal changes in tidal currents, wave climate and episodic events (see e.g., HARLEY et al., 2011; GALGANO and DOUGLAS, 2000; GALGANO et al. 1998; DEMAREST and LEATHERMAN, 1985). 
The challenge with temporal monitoring of shoreline at higher resolution is the lack of temporal cartographic information, which makes it difficult to determine the variability of the shoreline as well as its prediction. This shortage in temporal cartographic information is due to that fact that the techniques used for data collection such as photogrammetric restitution are either expensive or poor in terms of spatial resolution (see e.g., GONÇALVES et al., 2012a). More modern techniques such as LiDAR (Light Detection and Ranging) that are useful for monitoring coastal areas with vertical accuracy of $8-15 \mathrm{~cm}$ and a set of points spaced at least $1 \mathrm{~m}$ (without taking into account the processes of extraction of shoreline) are way out of reach for developing nations such as Brazil (e.g., GONÇALVES et al., 2012b). To circumvent shoreline monitoring problems at shorter temporal spans that are of benefit to coastal planning, GNSS are rapidly coming up as efficient tools that can provide quicker, all-weather, highly accurate and continuously updatable shoreline positional time series relevant for monitoring, thus enabling quicker management decisions to be undertaken, which may be of benefit to coastal engineering applications (see e.g., AWANGE and KIEMA 2013; GONÇALVES et al., 2012a,b; AHMAD and LAKHAN 2012; AWANGE 2012; KRUEGER et al. 2009; TANAJURA 2011 and RUGGIERO et al., 1999).

Use of GNSS to monitor Brazilian coastal areas, such as, Pernambuco have been reported , e.g., in Mendonça (2005) and Mendonça et al. (2006) who applied GNSS technology to measure the shoreline for morphological studies of Coroa do Avião in Itamaracá, Mallmann (2008) who studied the vulnerability on the beaches of the southern coast of Pernambuco, Rollnic (2008) who analyzed the dynamics of waves, circulation and transport of sediments in the coastal zone of the beaches in the metropolitan area of Recife, and Gregório (2009) who analyzed some aspects of shoreline in Recife. More recently, Gonçalves et al., (2012a,b) studied the trend of simple linear regression, robust estimation, and artificial neural networks using temporal data from different sources and demonstrated the importance of choosing a probabilistic model. Silva et al. (2013) used fuzzy logic to model and produce a thematic map containing the vulnerability of coastal erosion, while Gonçalves et al., (2013) simulated the effect of the shadows of the buildings constructed near the shoreline showing the importance of preserving distances between urban beaches and shorelines.

As a contribution to studies of monitoring of the shoreline based on GNSS techniques, this paper describes a consistent, low cost, and accurate monitoring approach that can detect different sectors with similar characteristics of evolution. The study area is the beach of Piedade and Boa Viagem where GNSS surveys were conducted during the years 2007, 2009, 2010 and 2012 for the purpose of preservation and enhancement of the coastal environment in-line with the aims of Coastal Management Act of the State of Pernambuco (Brazil) of promoting and supporting the conservation, restoration, and control of areas that are representative ecosystems of the coastal zone. 
This study is organized as follows: In section 2, the study area is presented along with its geographical coastal characteristics, census data, and sectorial division. Section 3 presents data and methodology used to undertake the shoreline change analysis. The results and analysis are presented in section 4 , and the study conclusion in section 5 .

\section{STUDY AREA}

With a range of $187 \mathrm{~km}$ of Atlantic ocean shoreline, Pernambuco coast was divided into 21 municipalities based on their geographic location. In the northern and southern boundaries are respectively the municipalities of Goiás and São José da Coroa Grande. The coast of Pernambuco has a diversity of ecosystems such as plain segments covered by coconut trees, remnants of Atlantic forest, estuaries with extensive mangroves, coral reefs, islands, among others, (MANSO et al., 2006).

The coast of Pernambuco is divided into three sectors: Northern sector, located between Olinda and Paraíba State, with a narrow plain. Eastern sector, between Olinda and Cabo de Santo Agostinho, characterized by Quaternary sedimentation that lies between the city of Recife and sandbanks of Barra da Jangada, Candeias and Brasilia Teimosa. The Southern sector that lies between Cabo de Santo Agostinho and the extreme south of the State, represented by the sediments of Cretaceous, Cabo and Estivas formations and the volcanic formations of Ipojuca (COUTINHO et al., 1997).

In the middle sector are Pleistocene marine terraces (7-11 m high) and Holocene (1-5 m high) designed during the last marine transgression. In addition to swamp's deposits, banks of sandstone or beachrocks are in some sectors (DOMINGUEZ et al., 1990). The beachrocks have a width average of 20 to $60 \mathrm{~m}$ and are 3-4 $\mathrm{m}$ in thickness. The beachrocks that are arranged parallel to shoreline protect the coast from the wave energy effect but can also generate erosion process at their ends (DOMINGUEZ et al., 1990, MANSO et al., 1995).

The study area includes the beaches of Pina and Boa Viagem, located in the southern Recife coast and Piedade that is situated in the northern coast of Jaboatão Guararapes, which together represents approximately $13 \mathrm{~km}$ of extension. Those beaches are urbanized and have suffered coastal erosion in recent decades.

Figure 1 shows a location map of Pernambuco state in northeastern Brazil, the extension of the state and in particular a polygon that define the municipalities of Recife and Jaboatão dos Guararapes.

According to Manso et al., (2006) the exponential population growth of Pernambuco state coastal zone accompanied by uncontrolled explosion of tourism activities precipitated its mischaracterization, which in some sectors around several municipalities is considered irreversible. Manso et al., (2006) report that the development and expansion of Recife was mainly along rivers and coastal zone. Over time, the beaches of Candeias, Piedade and south of Boa Viagem, which presented a stable shoreline began to have coastal erosion problems. It is believed that the erosion is related to the settlement done very close to the shoreline. 
Figure 1- Localization Map: Recife and Jaboatão dos Guararapes.

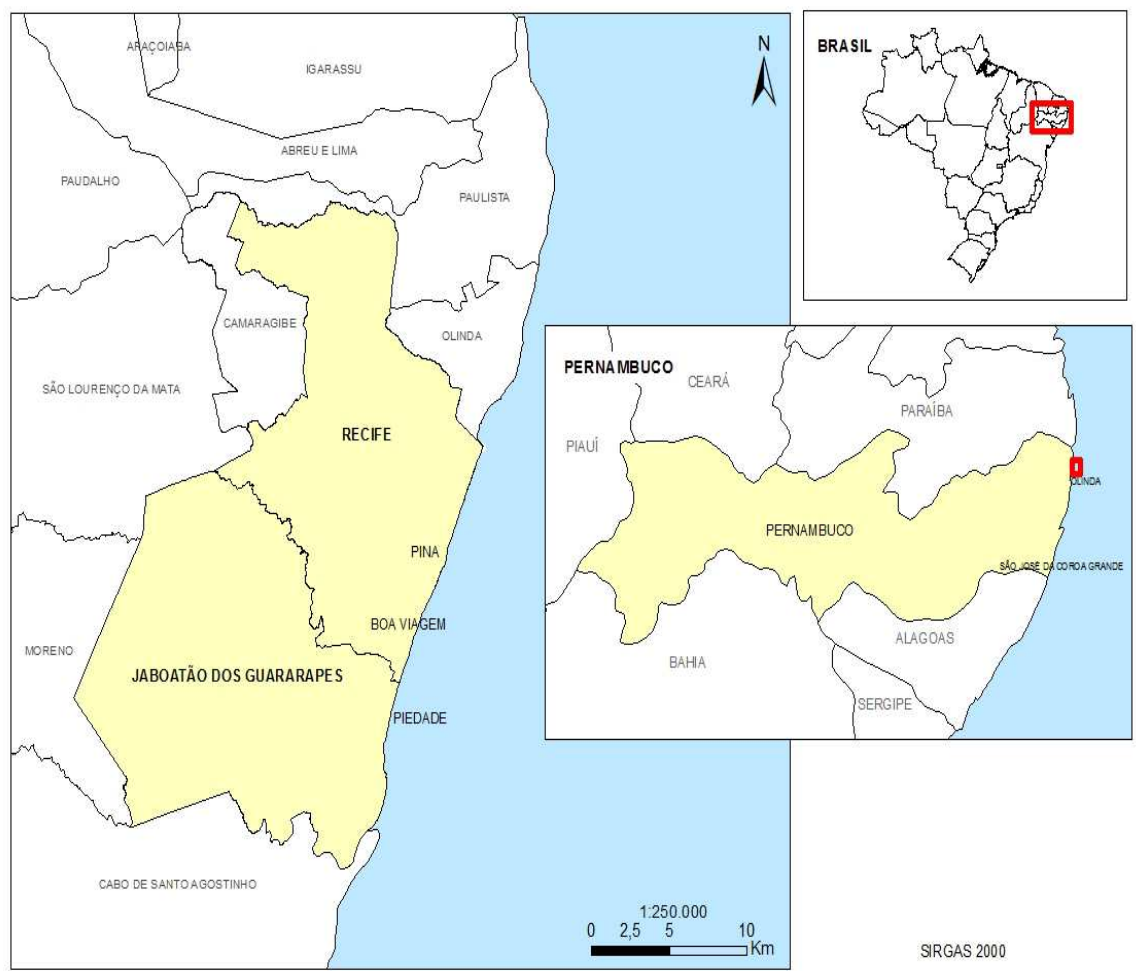

According Aureliano (2000), characterization of the urbanization of the city was through residential subdivisions, commercialization and industrialization. Since the last decades there has been a large rise in building constructions, condominiums and hotels along the waterfront.

Recife, according to the 2010 census, had a population of 1,537,704 inhabitants and has a land area of $218.498 \mathrm{~km}^{2}$, thus Recife has a very high population density of 7,037.61 inhabitants/ $\mathrm{km}^{2}$. The area and population for 2010 in the urban municipalities of Recife and Jaboatão dos Guararapes are presented in Table 1, totaling approximately to three and a half million inhabitants (IBGE, 2010). 
Table 1 - Total area and population in the urban area of Recife metropolitan region (Source: IBGE (2010)).

\begin{tabular}{c|c|c}
\hline Municipalities & Population (hab) & Area $\left.\mathbf{( k m}^{2}\right)$ \\
\hline Cabo de Santo Agostinho & 185,025 & 446.578 \\
\hline Camaragibe & 144,466 & 51.194 \\
\hline Jaboatão dos Guararapes & 644,620 & 258.566 \\
\hline Moreno & 56,696 & 196.071 \\
\hline Olinda & 377,779 & 41.659 \\
\hline Paulista & 300,466 & 97.364 \\
\hline Recife & $1,537,704$ & 218.498 \\
\hline São Lourenço da Mata & 102,895 & 262.157 \\
\hline Total & $3,349,651$ & $1,572.087$ \\
\hline
\end{tabular}

\subsection{Sectorial Division}

Figure 2 shows a satellite image of 2011 denoting the study area that was divided into specific sectors. The criterion used in the division was the behavior of the region's post-beach, whereby the data was analyzed according to five sectors located and distributed from north to south: Sector 1, Pina Beach and North Beach of Boa Viagem; Sector 2 - the center zone of Boa Viagem; Sector 3 - south of Boa Viagem beach until the beginning of riprap, Sector 4 - south of Boa Viagem riprap to the limit with Jaboatão dos Guararapes and Sector 5 - located north of Jaboatão dos Guararapes (beach of Piedade) until the beginning of the South riprap. Figure 2 (in red) shows an area covering $2.4 \mathrm{~km}$ in length that interrupts the two paths by the riprap (boulders of granite). This location was not mapped because it is in direct contact with an area of urban construction, demonstrating that within this stretch, coastal erosion problems are already part of society and require constant maintenance and rehabilitation works.

Sector 1 begins at the end of Brasília Teimosa riprap and continues southward with $2,905 \mathrm{~m}$ to a water flow channel at the building Canopus $\mathrm{n}^{\circ} 2594$ of Boa Viagem Avenue. This sector is characterized by a well developed post-beach, with the presence of vegetated dunes, with a distance of $\sim 120-140 \mathrm{~m}$ between the shoreline and the first urban obstacle. Going southwards, the post-beach becomes narrower without the presence of foredunes, which is the starting of Sector 2 and heads south to $1340 \mathrm{~m}$ to the intersection of Boa Viagem Avenue with Bruno Veloso street. Sector 2 is characterized by a post-beach without undergrowth and occurrence of coastal erosion. The average distance between the shoreline and the first urban obstacle is approximately 40 meters. There is also a steepening of the beach environment with the presence of berm and beachrocks on the beach face. 
Sector 3 starts at the intersection of Boa Viagem Avenue with Bruno Veloso street and heads south for $440 \mathrm{~m}$ to the beginning of the Boa Viagem riprap. It is characterized by a post-beach reduction to less than $10 \mathrm{~m}$, and at some points with the high tide reaching the wall of the containment, with clear indication of coastal erosion. Sector 4 is south of Boa Viagem riprap still in Recife following the direction of Jaboatão dos Guararapes (Piedade Beach) for a length of $2835 \mathrm{~m}$. A sandy beach without evidence of coastal erosion nor vegetation and foredunes characterized this sector. Sector 5 located north of Jaboatão dos Guararapes (beach of Piedade) heads towards south for about $880 \mathrm{~m}$ to the beginning of riprap. In this sector the post-beach is not limited by a pavement street but by the buildings that were built too close to the shoreline.

Figure 2 - Sectorial division.

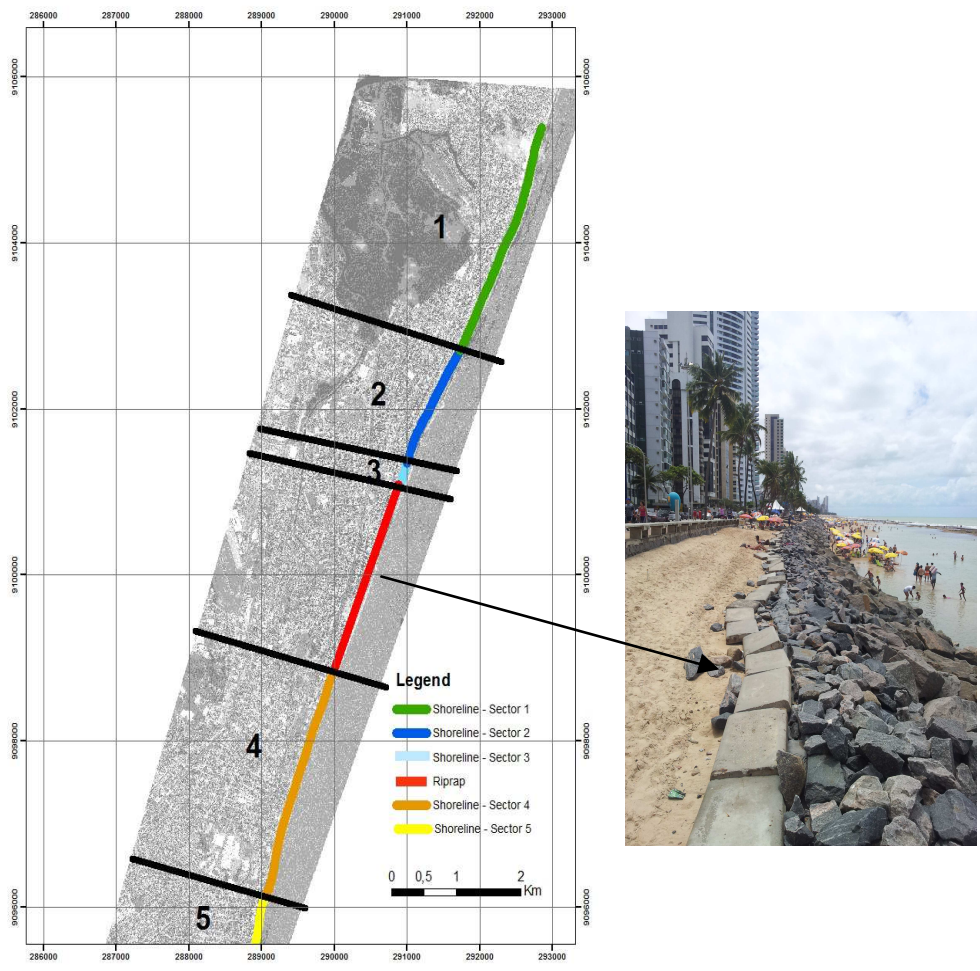

\section{METHODS}

The spatial positioning of the shoreline trajectory benefits from GNSS, using both the American GPS (Global Positioning System) and the Russian system 
GLONASS (Global Navigation Satellite system). The shoreline position trajectory was extracted using kinematic relative positioning method of GNSS, details of which can be found in Awange (2012), Monico (2008), El-Rabbany (2006), Seeber (2003) and Hofman-Wellenhof et al. (2001, 2008). In this method, the base receiver is placed at a base station of known coordinates, while the rover receiver is moved by a person walking on foot (or vehicle) on the feature of interest, in this case the shoreline. During data collection, a geodetic dual frequency receiver was placed at a base station at a location known as the Terceiro Jardim on Boa Viagem Avenue whose coordinates are latitude $08^{\circ} 06$ '30.16493 "S, longitude $34^{\circ} 53$ '17.32463 "W (SIRGAS-2000), geometric altitude $-1.433 \mathrm{~m}$ and orthometric height $4.533 \mathrm{~m}$ (IMBITUBA-SC). The base station receiver was configured to collect raw data every 3 seconds. The roving receiver was configured to store information in a data recording interval of 3 seconds in kinematic mode, with elevation mask of $10^{\circ}$ to reduce multipath and atmospheric related errors. The field team consisted of 4 or more members of LACCOST (Laboratory of Coastal Cartography) formed by graduate students in Cartographic Engineering or Geodetic Sciences and Technology of Geoinformation Post Graduation Program at UFPE with knowledge on geodetic survey. The staff were trained in advance to perform the mapping of the shoreline. For planning the survey, the team searched in the DHN (Diretoria de Hidrografia e Navegação) tide forecasts available to the State of Pernambuco site analyzing the day and the time for maximum high tide in the month chosen as shoreline indicator. In the case of Recife, the maximum tide is around 2.5 to $2.7 \mathrm{~m}$ depending of the month. The $2.4 \mathrm{~km}$ extension of shoreline takes around 3 hours for mapping generating more than 3,500 points with a horizontal accuracy better than $7.0 \mathrm{~cm}$.

Figure 3 shows the use of GNSS receivers in the study area on Boa Viagem beach. This type of survey has been effective and accurate for small areas of study as exemplified for the island of Ilha do Mel and the city of Matinhos in Paraná State, Brazil (Krueger et al., 2009) and also here in this case where the distance between the base station and the receiver in the study area is less than $5 \mathrm{~km}$.

The data collected in the field are stored simultaneously in the two receivers (base and rover) and post-processed with the use of Topcon processing software. The level of accuracy of the method with relative kinematic post-processing is about $10 \mathrm{~cm}$ and may reach a few centimeters if conditions are favorable (good satellite geometry, no multipath, short distance from the base line processing, etc.) (Seeber, 2003). 
Figure 3 - Base and rover receiver in the study area.

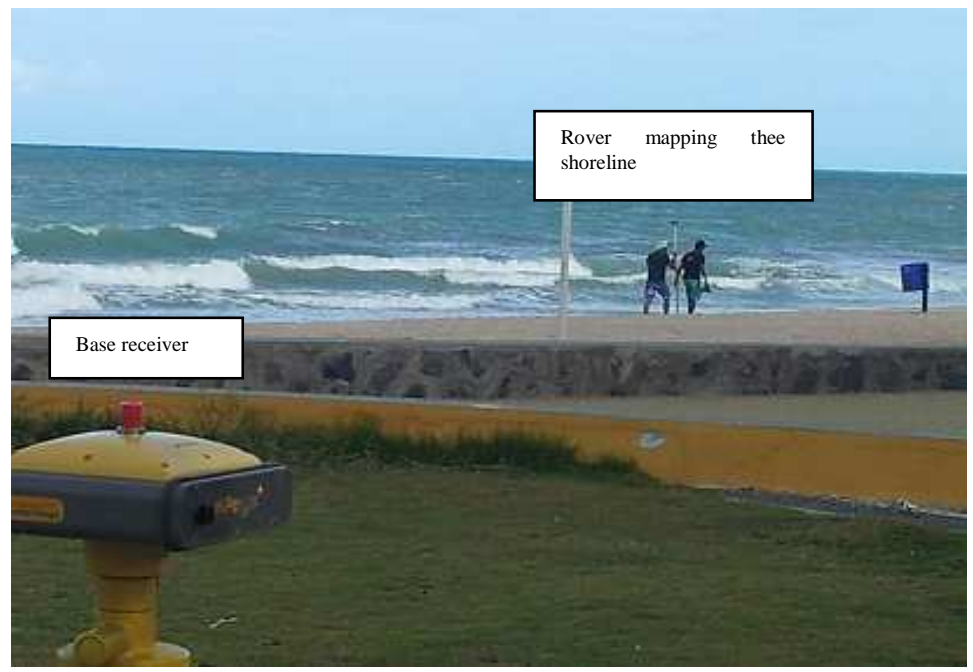

The calculation of the rate of change of shoreline considering the processes of advances and retreats were performed automatically in the free extension of ArcGIS software called Digital Shoreline Analysis System - DSAS (Thieler, 2009). This was done across distances of cross sections between the baselines, with intervals of $5 \mathrm{~m}$. Figure 4 shows an example of the shoreline and transects selected as base.

\subsection{Evaluation Criteria}

The displacements were evaluated for each sector using the following statistical methods:

(1) The arithmetic mean of the variation of the shoreline from the cross section the samples collected for each sector from the following pairs of years (2007 and 2009), (2009 and 2010) and (2010 and 2012 ) were calculated using:

$$
\bar{x}=\frac{1}{n} \sum_{i=1}^{n}\left(\text { SLPrevious }_{i}-\text { SLBack }_{i}\right),
$$

where $\left(\right.$ SLFrowows $\left.-S L B \propto \sigma W_{1}\right)$ is the distance between shorelines considering the years studied in the $i$ th cross section, and $n$ is the number of sections.

(2) The standard deviation was obtained by taking the square root of the variance of the shoreline position as:

$$
\sigma=\sqrt{\left.\left.\frac{1}{n-1} \sum_{i=1}^{n}\left(\text { SLPrevious }_{i}-\text { SLBack }_{i}\right)\right)-\bar{x}\right)^{2}}
$$


(3) The maximum value in meters found in cross sections.

(4) The minimum value in meters found in cross sections.

(5) The shoreline rates of variations by the endpoint (EPR - end point rate) method. The EPR method uses two points to determine the shoreline rate of change. In this case, we calculated the variations of the distance between the cross sections using the base line by pairs (2007 and 2009), (2009 and 2010) and (2010 and 2012). For example, between 2007 and 2009 is 2 years, and this is the number considered as dividend to be taken in this specific comparison. The rate is expressed in $\mathrm{m} /$ year. Examples of papers discussing and using this method are Genz et al., (2007), Crowell et al., (1997, 1999) and Dolan et al., (1991).

Figure 4 - Cross sections between shoreline of 2007 and 2012.

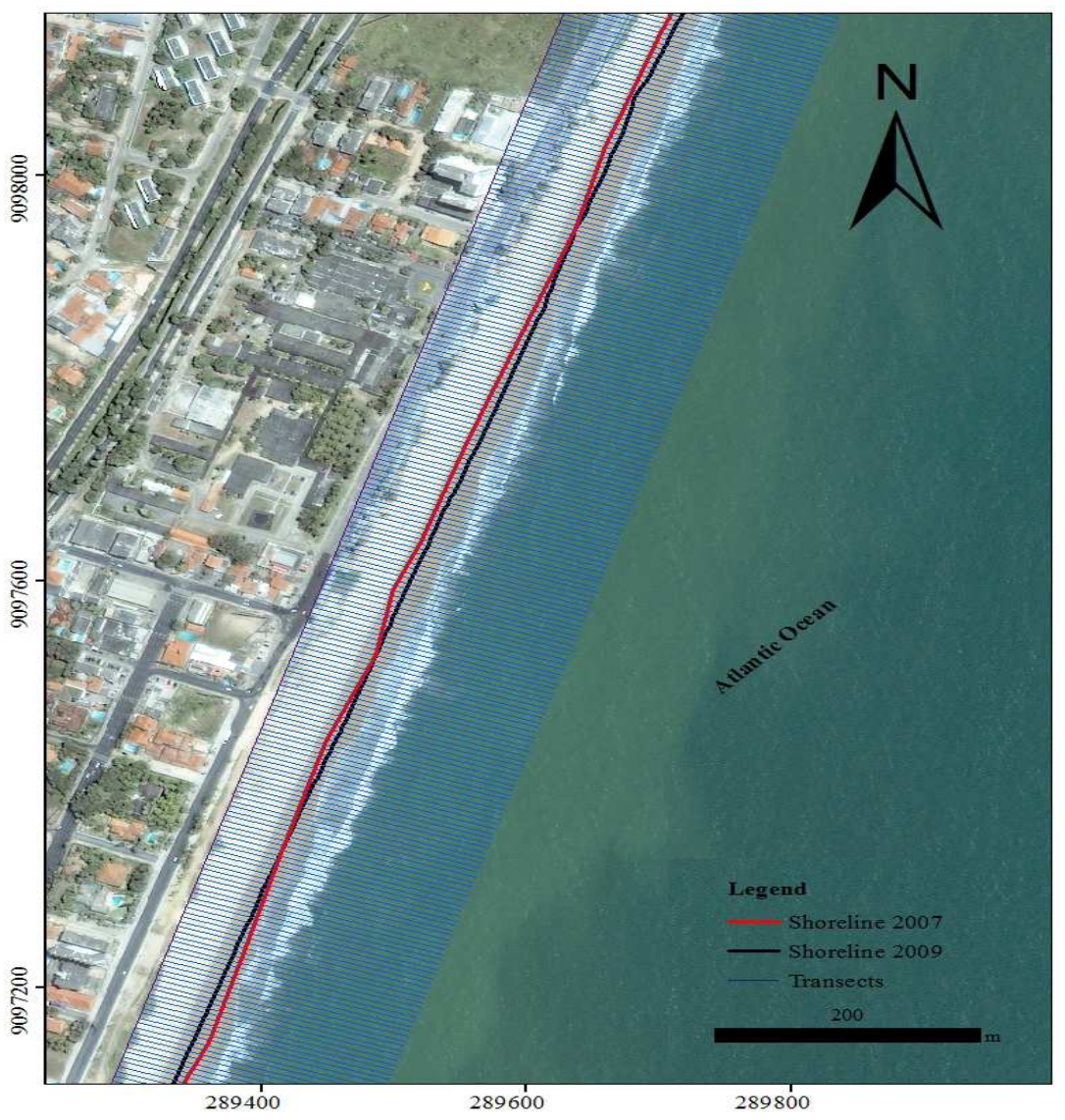

Bol. Ciênc. Geod., sec. Artigos, Curitiba, v. 20, nº 3, p.701-719, jul-set, 2014. 


\section{RESULTS AND DISCUSSION}

Table 2 presents the results observed for the five sectors and show; the number of cross sections at each $5 \mathrm{~m}$, the minimum and maximum displacement, the arithmetic mean, the standard deviation of observations and rates of changes by end point method.

In Table 2, it is possible to analyze the behavior of the sectors for 5 years divided by intervals. During the interval 2007-2009 the average position of the shoreline was negative indicating retreat in the analyzed period with values ranging from $16.33 \mathrm{~m}$ in sector 5 to $1.61 \mathrm{~m}$ in sector 4 . The interval $2009-2010$ yielded positive values indicating advances of shoreline ranging from $0.32 \mathrm{~m}$ in sector 5 until $2.62 \mathrm{~m}$ in sector 3. Interval 2010-2012 is observed to have stretches of backward and forward highlighting the decline in average of $6.02 \mathrm{~m}$ in section 5 and further advancement average for the sector 1 with $2.38 \mathrm{~m}$.

Table 2 Values of the displacements $(\mathrm{m})$ of shorelines by sectors, between the years 2007/2009, 2009/2010, 2010/2012.

\begin{tabular}{|c|c|c|c|c|c|c|}
\hline Sectors (S)/Year & $\begin{array}{c}\text { Number } \\
\text { of } \\
\text { cross } \\
\text { sections } \\
\text { each } 5 \mathrm{~m}\end{array}$ & $\begin{array}{l}\text { Arithmetic } \\
\text { Mean } \\
\text { (m) }\end{array}$ & $\begin{array}{l}\text { Minimu } \\
\text { m } \\
\text { Displace- } \\
\text { ment } \\
(\mathrm{m})\end{array}$ & $\begin{array}{l}\text { Maximum } \\
\text { Displace } \\
\text { ment } \\
\text { (m) }\end{array}$ & $\begin{array}{l}\text { Standard } \\
\text { deviation } \\
\text { (m) }\end{array}$ & $\begin{array}{c}\text { Anual } \\
\text { avarage } \\
\text { Displace- } \\
\text { ment } \\
\text { (m/year) }\end{array}$ \\
\hline S1 $2007-2009$ & 581 & -2.38 & -14.88 & 13.04 & 6.48 & -1.19 \\
\hline S2 $2007-2009$ & 268 & -8.03 & -13.94 & 5.76 & 5.12 & -4.02 \\
\hline S3 2007 - 2009 & 88 & -9.48 & -14.98 & 1.48 & 3.74 & -4.74 \\
\hline S4 2007 - 2009 & 567 & -1.61 & -12.96 & 10.42 & 7.36 & -6.48 \\
\hline S5 $2007-2009$ & 176 & -16.33 & -29.98 & 0.38 & 7.77 & -8.16 \\
\hline S1 $2009-2010$ & 581 & 1.60 & -4.60 & 10.61 & 2.58 & 1.60 \\
\hline S2 $2009-2010$ & 268 & 1.14 & -4.67 & 10.96 & 3.55 & 1.14 \\
\hline S3 $2009-2010$ & 80 & 2.62 & -1.06 & 6.98 & 2.34 & 2.62 \\
\hline S4 2009 - 2010 & 567 & 1.19 & -8.34 & 7.40 & 3.03 & 1.19 \\
\hline S5 2009 - 2010 & 123 & 0.32 & -4.79 & 5.22 & 2.43 & 0.32 \\
\hline S1 $2010-2012$ & 581 & 2.38 & -3.30 & 13.48 & 2.81 & 1.19 \\
\hline S2 $2010-2012$ & 268 & 1.09 & -5.78 & 9.68 & 3.47 & 0.55 \\
\hline S3 2010 - 2012 & 80 & -0.07 & -5.72 & 3.76 & 2.18 & -0.04 \\
\hline S4 $2010-2012$ & 567 & 0.79 & -10.92 & 10.08 & 4.39 & 0.40 \\
\hline S5 2010 - 2012 & 123 & -6.02 & -11.50 & -2.04 & 2.66 & -3.01 \\
\hline
\end{tabular}

In Table 2, in the column number of cross sectors for the sector 3 of 20072009 there were 88 cross sections, that number goes to 80 cross sections in the same sector for the periods 2009-2010 and 2010-2012. This reduction is due to the increase in erosion at the site, leading to an increase in (riprap), thereby decreasing the shoreline spatial monitoring since this is done at a range of sandy beach. The 
same happened also in sector 5 whit containment occurring north of the increase in erosion and decreasing the number of cross sections from 176 to 123.

Figure 5 shows a bar chart built from the observed results of the shoreline rates of changes by end point method presented in the last column of Table 2. From the analysis of this bar chart we can observe the variation of the rate by the method of endpoint (EPR) represented in m/year. In sector 1 between 2007-2009, a retreat of shoreline by a value of $1.19 \mathrm{~m} / \mathrm{year}$ is seen. Then for the years 2009-2010 and 20102012 they advance (positive value) reaching of $1.60 \mathrm{~m} / \mathrm{year}$ and then slightly decrease to $1.19 \mathrm{~m} /$ year respectively. The situation for 2007-2009 intervals in all sectors shows a period of shoreline retreat rates reaching around $8 \mathrm{~m} /$ year in sector 5. On the other hand, for 2009-2010, the opposite behavior characterized by the advance in the sectors analyzed reached $2.6 \mathrm{~m} /$ year. For the 2010-2012 interval, sectors 1, 2 and 4 shows positive values (advance), stability in sector 3 and a retreat of $3.01 \mathrm{~m} /$ year for the sector 5 .

Figure 5 - Shorelines average annual rate of displacement by sectors, between the years 2007/2009, 2009/2010, 2010/2012.

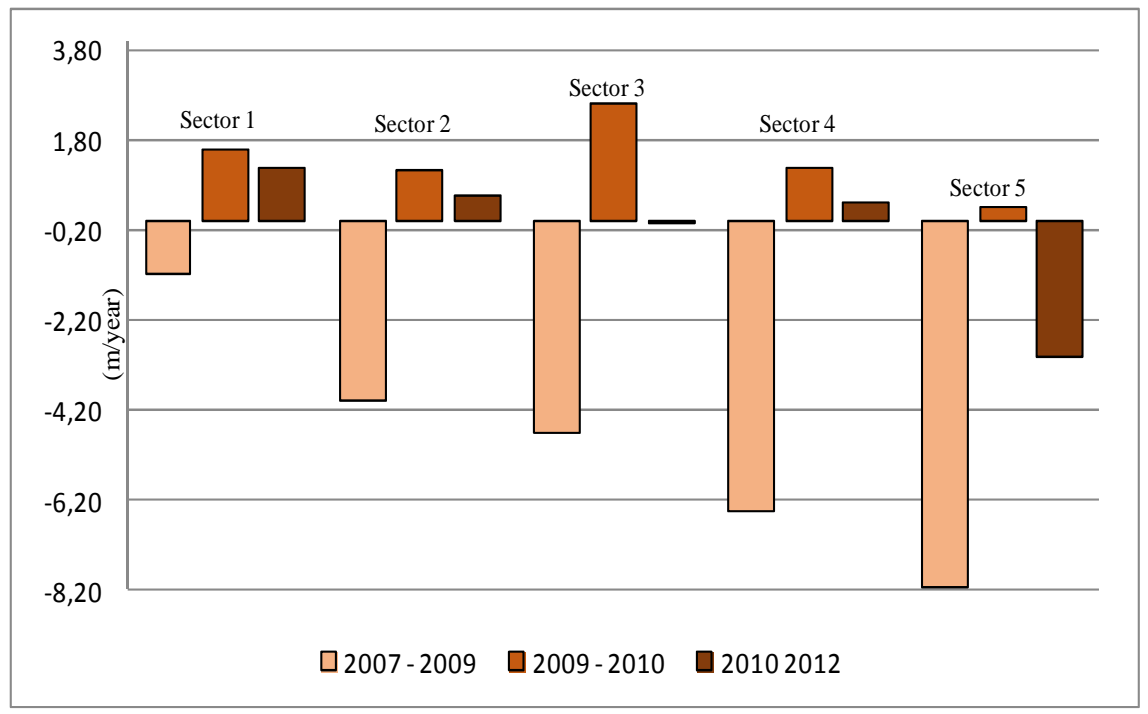

For a representative analysis of the values found in the average annual rates of displacement ( $\mathrm{m} /$ year), Table 3 presents a model for classifying the advances and retreats of the shoreline according to Thieler and Hammar-Klose (2000), and also show the classification of shoreline rates obtained. 
Table 3 - Classification of average annual rates of shoreline according to Thieler and Hammar-Klose (2000).

\begin{tabular}{|c|c|c|c|c|c|}
\hline \multicolumn{6}{|c|}{ Classification of mean shoreline annual rates } \\
\hline \multirow[b]{2}{*}{ Classification } & \multicolumn{2}{|c|}{ Retreat } & \multirow{2}{*}{$\begin{array}{l}\text { Stability } \\
\text { Moderate }\end{array}$} & \multicolumn{2}{|c|}{ Advance } \\
\hline & Very High & High & & Low & Very Low \\
\hline $\begin{array}{c}\text { Shoreline } \\
\text { advance/retreat } \\
\text { (m/year) }\end{array}$ & $<-2.0$ & $-2.0--1.0$ & $-1.0-1.0$ & $1.0-2.0$ & $>2.0$ \\
\hline Sectors/interval & & & & & \\
\hline S1 (2007 - 2009) & & High & & & \\
\hline S1 $(2009-2010)$ & & & & Low & \\
\hline S1 $(2010-2012)$ & & & & Low & \\
\hline S2 (2007 - 2009) & Very High & & & & \\
\hline S2 (2009-2010) & & & & Low & \\
\hline S2 $(2010-2012)$ & & & Moderate & & \\
\hline S3 (2007 - 2009) & Very High & & & & \\
\hline S3 $(2009-2010)$ & & & & & Very Low \\
\hline S3 $(2010-2012)$ & & & Moderate & & \\
\hline S4 (2007 - 2009) & Very High & & & & \\
\hline S4 (2009-2010) & & & & Low & \\
\hline S4 $(2010-2012)$ & & & Moderate & & \\
\hline S5 (2007 - 2009) & Very High & & & & \\
\hline S5 $(2009-2010)$ & & & Moderate & & \\
\hline S5 (2010 - 2012) & Very High & & & & \\
\hline
\end{tabular}

Table 3 illustrates fluctuations in classification of shoreline rates over the sectors and periods. For sector 2 (2007-2009), sector 3 (2007-2009), sector 4 (20072009) sector 5 (2007-2009) and sector 5 (2010-2012) the rates of shoreline retreated and was considered as a very high retreat. On the other hand considering advances' rates as low and very low, there are five cases found in sector 1 (2009 - 2010), sector 1 (2010 - 2012), sector 2 (2009 - 2010), section 3 (2009 - 2010) and sector 4 (2009 - 2010). Finally there was no change classified as moderate (considered stable) in sector 2 (2010 - 2012), sector 3 (2010 - 2012), sector $4(2010$ - 2012) and sector 5 (2009 - 2010).

The seasonal shoreline transport change processes possibly are related to the granulometry characteristics of Pina and Boa Viagem beaches. During the rainy seasons for example, a very thin until medium size of sediments is found. The medium sand lies in the beach in the central part of the Boa Viagem, while the thin 
sand is observed at the edges, and very thin sand in north of Pina. During dry seasons sediments are dominantly composed of thin sand (Gregório et al., 2004a). But the thin sand sediments is composed mostly of these beaches (Gregório, 2009). The sediment characteristics of the Pina and Boa Viagem beaches showed a moderate energy sedimentary environment (Gregório, 2009, Gregório et al., 2004a, 2004b). The predominance of thin sand in the study area is easily mobilized by the action of waves and tides, influencing the shoreline positional variation toward the mainland or in the opposite direction, toward the ocean.

\section{CONCLUSIONS}

The kinematic GNSS method used for shoreline monitoring in this study has the advantages of being able to produce consistent data for temporal analysis, be applied in the field by a small team, be quick for small areas and have low operating costs when compared with LiDAR (Light Detection and Ranging) for example. LiDAR needs an airplane team, whose shoreline data can also be detected from digital terrain models applied to coastal zones and are much more expensive than GNNS but remains very important for coastal applications, see e.g., Awange and Kiema (2013, chapter 24), Gibeaut et al., (2001), and Gorman et al. (1998). The GNSS disadvantages are; it can become unfeasible for coastal mangroves, rocky shores or, for example, for monitoring very large areas can become costly.

Through a short term temporal analysis of five years for Boa Viagem and Piedade beaches, it was possible to verify that the shoreline is constantly changing. These changes were characterized by sectors that may experience different periods of advances, stability and retreats. Sector 4 (2007-2009) for instance showed retreat rate considered as very high, then between (2009-2010) changed to low, and over the period (2010 -2012) fell to moderate.

During the time series monitoring that began in 2007 , the field team also notice the increase in containment works in the case of riprap (boulders of granites) indicating human intervention in sectors with serious problems of coastal erosion such as in the central part of the Boa Viagem beach with a length of $2.4 \mathrm{~km}$ (2012) that requires constant maintenance. For this specific site of the beach, where riprap shoreline rates were not calculated (on purpose), erosion appears to be increasing over time detected from the decreasing extension of monitoring, which is a worrying trend for urban planning. The purpose of this structure made with rocks is to protect the coast with the mission of removing the wave energy and protect the urban area. This can generate a problem since it can affect the dynamics of the beach and sediment transports. The contention of the sea, sometimes, without planning can become a problem because it requires constant care over time.

It is recommended that shoreline monitoring for the study area be continued since this area will in future receive sand replenishment according to Pernambuco State and possibly develop a complex shoreline behavior such as observed in this study.

Bol. Ciênc. Geod., sec. Artigos, Curitiba, v. 20, nº 3, p.701-719, jul-set, 2014. 


\section{ACKNOWLEDGMENTS}

The authors are grateful to the support of: FACEPE/CNPq, PPP/APQ-12421.07/10 - "Monitoramento e mapeamento costeiro do uso e ocupação do solo nos municípios de Recife e Jaboatão dos Guararapes" Project; the laboratory of coastal cartography (LACCOST), the Department of Cartographic Engineering (UFPE); the Department of Spatial Sciences (Curtin University). RMG acknowledge the support of Post-Doctoral CNPq scholarship (233170/2013-8). This is a TiGER No. 573.

\section{REFERENCES}

ANGULO, R. J. Classificação da Costa Paranaense com base na sua Dinâmica, como Subsídio à Ocupação da Orla Litorânea. Boletim Paranaense de Geociências. Curitiba, Editora da UFPR, n. 44, p.7-17, 1996.

AHMAD, S. J.; LAKHAN, V. C. GIS-Based Analysis and Modeling of Coastline Advance and Retreat Along the Coast of Guyana. Marine Geodesy, Taylor \& Francis Group, LLC, 35, p.1-15, 2012.

ALMEIDA, H. R. R. C. Séries temporais de imagens suborbitais e orbitais de alta resolução espacial na avaliação da morfodinâmica praial no município do Cabo de Santo Agostinho -PE. Dissertação de Mestrado em Ciências Geodésicas e Tecnologias da Geoinformação, UFPE, 2008. 124p.

AURELIANO, J. T. Balnealidade das praias de Pernambuco: $O$ núcleo Metropolitano. Dissertação de Mestrado em Gestão e Políticas Ambientais, UFPE, 2000. 113p.

AWANGE, J. L. Environmental monitoring using GNSS Global Navigations Satellite Systems, Springer-Verlag, 2012, 382p.

AWANGE, J.; KIEMA, J. B. Environmental Geoinformatics. Springer-Verlag, 2013, 541p.

BAPTISTA, P. CUNHA, T., BERNARDES, C., GAMA C., FERREIRA, O., DIAS, A. A Precise and Efficient Methodology to Analyse the Shoreline Displacement Rate. Journal of Coastal Research, 27, 2 p.223-232, 2011.

COUTINHO, P. N.; LIMA, A.T. O.; LIMA, A. T. O.; QUEIROZ, C. M.; FREIRE, G. S. S.; ALMEIDA, L. E. S. B.; MAIA, L. P.; MANSO, V. A. V.; BORBA, A. L. S.; MARTINS, M. H. A.; DUARTE, R. X., 1997. Estudos da erosão marinha nas praias de Piedade e de Candeias e no estuário de Barras das Jangadas. Município de Jaboatão dos Guararapes - PE. Relatório Técnico, UFPE, Recife, 154p.

CROWELL, M.; DOUGLAS, B.C., and LEATHERMAN, S.P. On forecasting future U.S. shoreline positions: a test of algorithms. Journal of Coastal Research, 13(4), p.1245-1255, 1997.

CROWELL, M.; HONEYCUTT, M., and HATHEWAY, D. Coastal erosion hazards study: phase one mapping. Journal of Coastal Research, n.28, p.10 20, 1999.

DEMAREST, J. M.; LEATHERMAN, S. P. Mainland influence on coastal transgression: Delmarva Peninsula. Marine Geology. n. 63,. p. 19-33, 1985. 
DOLAN, R.; FENSTER, M.S., and HOLME, S.J. Temporal analysis of shoreline recession and accretion. Journal of Coastal Research, 7(3), 723-744, 1991.

DOMINGUEZ, J. M. L.; BITTENCOURT, A. C. S. P.; LEÃO, Z. M. A. N.; AZEVEDO, A. E. G.,. Geologia do quaternário costeiro do Estado de Pernambuco. Revista Brasileira de Geociências, São Paulo, 20, p.208 - 215, 1990.

EL-RABBANY, A. Introduction to GPS global positioning system, $2^{\text {nd }}$ edn. Artech House, Boston, 2006.

GAlgano, F. A.; DOUGlaS, B. C.; LEATHERMAN, S. P. Trends and variability of shoreline position. Journal of Coastal Research. n.26, p.282291, 1998.

GALGANO, F. A.; DOUGLAS, B. C. Shoreline Position Prediction: Methods and Errors. Environmental Geosciences. v.7, n.1, p.1-10, 2000.

GENZ, A. S., FLETHCER, C. H., DUNN, R. A., FRAZER L. N., ROONEY J. J. The Predictive Accuracy of Shoreline Change Rate Methods and Alongshore Beach Variation on Maui, Hawaii. Journal of Coastal Research, n.23(1)p. 87$105,2007$.

GIBEAUT, J. C.; HEPNER T.; WALDINGER R.; ANDREWS J.; GUTIERREZ R.; TREMBLAY T. A.; SMYTH R.; XU L. Changes in gulf shoreline position, Mustang, and North Padre Islands, Texas. A report of the Texas Coastal Coordination Council pursuant to National Oceanic and Atmospheric Administration. Bureau of Economic Geology, The University of Texas, Austin Texas, pp. 30, 2001.

GONÇAlVES, R. M.; COELhO, L. D. S; KRUEGER, C. P.; HECK, B. Modelagem preditiva de linha de costa utilizando redes neurais artificiais. Boletim de Ciências Geodésicas, v.16, p.420-444, 2010.

GONÇALVES, R. M.; AWANGE, J.; KRUEGER, C. P.; HECK, B.; COELHO, L. A comparison between three short-term shoreline prediction models. Ocean \& Coastal Management, v. 69, p. 102-110, 2012 a.

GONÇALVES, R. M.; AWANGE, J.; KRUEGER, C. P. GNSS-based monitoring and mapping of shoreline position in support of planning and management of Matinhos/PR (Brazil). Journal of Global Positioning Systems (Print), v.11, p.156-168, 2012 b.

GONÇALVES, R. M.; PACHECO, A. D. P.; TANAJURA, E. L. X.; SILVA, L. M. Urbanização costeira e sombreamento na praia de Boa Viagem, Recife-PE, Brasil. Revista de Geografía Norte Grande, 54, p.241-255, 2013.

GORMAN L.; MORANG A.; LARSON R. Monitoring the coastal environment; Part IV: mapping, shoreline changes, and bathymetric analysis. Journal of Coastal Research (14): P.61-92, 1998.

GREGÓRIO, M. N. 2004a. Sedimentologia e morfologia das praias do pina e da boa viagem, Recife( PE)-Brasil. Dissertação de Mestrado em Oceanografia, UFPE, 2004 a. 
GREGÓRIO, M. N., ARAÚJO; T. M. C.; VALENÇA, L. M. M., 2004b. Variação sedimentar das praias do Pina e da Boa Viagem, Recife (PE) - Brasil. Tropical Oceanography, 32(1):39-52, 2004 b.

GREGÓRIO, M. N. Evolução da linha de costa e caracterização da plataforma continental interna adjacente à cidade do Recife - PE. Tese de doutorado em Oceanografia, UFPE, 2009, 173p.

HARLEY, M. D.; TURNER, I.L.; SHORT, A.D.; RANASINGHE, R. Assessment and integration of conventional, RTK-GPS and image-derived beach survey methods for daily to decadal coastal monitoring. Journal of Coastal Engineering, n.58, p.194-205, 2011.

HOFMAN-WELLENHOF B., LICHTENEGGER H., COLINS J. Global positioning system: theory and practice, $5^{\text {th }}$ edn. Sprienger, Wien, 2001.

HOFMAN-WELLENHOF B., LICHTENEGGER H., WASLE E. GNSS global navigation satellite system: GPS, GLONASS, Galileo and more. Sprienger, Wien, 2008.

IBGE (Instituto Brasileiro de Geografia e Estatística). Mapa de distribuição da população 2010, disponível em Internet: http://www.ibge.gov.br/home/ geociencias/geografia/mapas_doc1.shtm acessado em 13/07/2012.

JACKSON, C. W. Jr., ALEXANDER, C. R., BUSH, D. M. Application of the AMBUR R package for spatio-temporal analysis of shoreline change: Jekyll Island, Georgia, USA. Computers \& Geosciences, 31, p.199-207, 2012.

KRUEGER, C. P.; GONÇALVES, R. M.; HECK, B. Surveys at the coast of Paraná,Brazil, to determinate the temporal coastal changes. Journal of Coastal Research, v.1, p.632-635, 2009.

MALlMANN, D.L.B. Vulnerabilidade do Litoral Sul de Pernambuco à Erosão. Dissertação de Mestrado em Oceanografia, UFPE. 2008. 61p.

MANSO, V. A. V.; COUTINHO, P. N.; LIMA, A.T. O.; MEDEIROS, A. B.; ALMEIDA, L. E. S. B.; BORBA, A. L. S.; LIRA, A. R. A.; PEDROSA, F. J. A.; CHAVES, N. S.; DUARTE, R. X.; IVO, P. S. Estudos da erosão marinha na praia da Boa Viagem. Recife. Relatório Técnico, Convênio ENLURB/FADE/LGGM - UFPE. Recife, 1995, 98p.

MANSO, V. A.; COUTINHO, P. N.; GUERRA N. C.; SOARES JR., C.F.A. Erosão e progradação do litoral brasileiro - Capítulo Pernambuco, Dieter Muehe, organizador - Brasília, Ministério do Meio Ambiente, MMA, 2006, p.179 196.

MENDONÇA, F.J.B. Posicionamento de alta resolução adequação e aplicação à morfologia costeira.. Tese de doutorado em Oceanografia, UFPE, 2005, 94p.

MENDONÇA, F. J. B.; LIMONGI,C. M.; ROLLNIC,M. Morphogenesis of the Coroa do Avião, a Sand Bank/Barrier Islet at Northeastern-Brazil. Journal of Coastal Research, v.SI-39, p.290-293, 2006.

MONICO, J.F.G. Posicionamento pelo GNSS: descrição, fundamentos e aplicações. 2. Ed. São Paulo: Editora UNESP, 2008 v.1 476p. 
RIBEIRO, G. P. Tecnologias digitais de geoprocessamento no suporte à análise espaço-temporal em ambiente costeiro. Tese (Doutorado) Curso de PósGraduação em Geografia da Universidade Federal Fluminense - UFF, Rio de Janeiro-RJ, 2005.

ROCHA, C. P.; ARAÚJO, T.C.M.; MENDONÇA, F.J.B. Aplicação de técnicas de posicionamento GPS tridimensional para localizar linhas de costa: estudo de caso na praia de Boa Viagem, Recife/PE, Brasil. Revista da Gestão Costeira Integrada, n.8, p.127-137, 2008.

ROLLNIC, M. Hidrologia, Clima de Onda e Circulação no Litoral da Região Metropolitana do Recife - Implicações para o Transporte de Sedimentos e Estabilidade da Costa. Tese de Doutorado em Oceonografia, UFPE. 2008. 132p.

RUGGIERO, P.; CÔTÉ, J.; KAMINSKY G.; GELFENBAUM, G. Scales of Variability along the Columbia River Littoral Cell. Proceedings of Coastal Sediments, ASCE, p.1692-1707, 1999.

SEEBER, G. Satellite Geodesy: Foundations, Methods and Aplications. Berlin-New York, Walter de Gruyter. 2 nd revised edition, 2003, 589p.

SILVA, L.M.; GONÇALVES, R. M.; LIRA, M. M. S.; PEREIRA, P. S. Modelagem fuzzy aplicada na detecção da vulnerabilidade à erosão costeira. Boletim de Ciências Geodésicas, v.19, p.746-764, 2013.

SMITH, M. J., CROMLEY, R. G. Measuring Historical Coastal Change using GIS and the Change Polygon Approach. Transactions in GIS, 16(1), p.3-15, 2012.

STOCKDON, H. F., SALLENGER JR., ASBURY H., JEFFREY, H. LIST, HOLMAN. R. A. Estimation of Shoreline Position and Change using Airborne Topographic Lidar Data. Journal of Coastal Research, 18, 3, p.502$513,2002$.

TANAJURA, E. L. X.; KRUEGER, C. P.; GONÇALVES, R. M. Análise da Acurácia dos Métodos Cinemáticos de Posicionamento GPS em Aplicações Costeiras. Boletim de Ciências Geodésicas, v.17, n.1, p. 23-36, 2011.

THIELER, E. R., DANFORTH W. W. Historical Shoreline Mapping (I): Improving Techniques and Reducing Positioning Errors. Journal of Coastal Research, 10, 3, p.549-563, 1994.

THIELER, E. R. and HAMMAR-KLOSE E. S. National Assessment of Coastal Vulnerability to Sea-Level Rise: Preliminary Results for the U.S. Gulf of Mexico Coast. U.S. Geological Survey. Woods Hole, Massachusetts, 2000.

THIELER, E. R.; HIMMELSTOSS, E. A.; ZICHICHI, J. L.; ERGUL, A. Digital Shoreline Analysis System (DSAS) version 4.0 - An ArcGIS extension for calculating shoreline change, U.S. Geological Survey Open-File Report 20081278. *current version 4.3, 2009.

TZATZANIS, M., WRBKA, T., SAUBERER, N. Landscape and vegetation responses to human impact in sandy coasts of Western Crete, Greece. Journal for Nature Conservation 11 (3), 187-195, 2003. 
VELOSO-GOMES, A., BARROCO, A.R., PEREIRA, C.S., REIS, H., CALADO, J.G., FERREIRA, M.D.C., FREITAS, M. BISCOITO. Basis for a national strategy for integrated coastal zone management e in Portugal. Jornal of Coastal Conservation 12, p.3-9, 2008.

(Recebido em janeiro de 2014. Aceito em junho de 2014). 